\title{
ARTICLES
}

\section{E pluribus unum? The Manifold Meanings of Sovereignty}

\author{
Raf Geenens
}

Few concepts are of such perennial interest to legal and political thought as the concept of sovereignty. The idea of sovereignty has been - and continues to be - a cornerstone in the constitutional structures of our world. And in combination with the prefix 'popular' it is a staple of the discourse of democracy. In the last years, however, the concept has received a high number of death warrants and even the occasional 'requiem'. ${ }^{1}$ Yet for now, the concept simply refuses to leave the stage. The death warrants even vivify the debate, thereby confirming the tenacity and importance of the idea of sovereignty. ${ }^{2}$ Every reflection on the demise of sovereignty it seems demonstrates just how deep the idea of sovereignty is woven into the fabric of our political and legal world.

In this article, I will not contribute to the debate on sovereignty, at least not directly. I will not make claims about the 'true' or 'proper' meaning of sovereignty, and I will mostly abstain from statements about the status of sovereignty in today's complex world. Instead, this text is conceived as a taxonomic exercise. Due to its long and winding history, the term 'sovereignty' has taken up a bulky appearance, carrying with it an unusually broad range of meanings. The modest aim of my text is to create some clarity by providing a - probably not very controversial - classification of these different meanings.

This is not the same thing as a study of the different entities that can be called sovereign or that act in a sovereign manner. I will not provide a taxonomy of sovereign institutions, nor an inquiry into how, say, state sovereignty works in practice. I will also not attempt to recount the history of the notion of sovereignty, nor to provide an overview of different theories of sovereignty. ${ }^{3}$ Inevitably, various thinkers of sovereignty will be mentioned, but my article is certainly not a comprehensive introduction to the - by now very broad - field of philosophical reflection on sovereignty. Even important doctrines, such as the English concep-

1 Michel Leroy, 'Requiem pour la souveraineté, anachronisme pernicieux,' in Présence du droit public et des droits de l'homme: Mélanges offerts à Jacques Velu (Brussels: Bruylant, 1992), 91-106.

2 Samantha Besson gives a good overview of the many intellectual conflicts caused by the concept of sovereignty throughout its history. See Samantha Besson, 'Sovereignty in Conflict,' European Integration online Papers 8(15) (2004).

3 Two recent books offer a summary of the term's historical trajectory: Amnon Lev, Sovereignty and Liberty (London and New York: Routledge, 2014) and Dieter Grimm, Sovereignty. The Origin and Future of a Political and Legal Concept (New York: Columbia University Press, 2015). 
tion of parliamentary sovereignty or the seminal idea of popular sovereignty, will only be touched upon very briefly.

Instead, I will limit myself to asking what we mean when we call a person - or a group of persons or an institution - sovereign. The term is used in a variety of contexts, but what exactly do we try to convey when using the words 'sovereign' or 'sovereignty'? I will argue that, when saying that $\mathrm{X}$ is sovereign, we can mean five very different things. ${ }^{4}$ To list them very briefly: it can mean that $\mathrm{X}$ holds the capacity to force everyone into obedience, that $\mathrm{X}$ makes the laws, that the legal and political order is created by $\mathrm{X}$, that $\mathrm{X}$ holds the competence to alter the basic norms of our legal and political order, or that $\mathrm{X}$ is independently active on the international stage.

Below, I will discuss each of these five meanings separately, and I will strongly focus on their differences. Of course, there are many relations between them, and it goes without saying that entities that are sovereign in one of these senses are often also sovereign in several others. But it is my contention that political and legal theorists are all too often misled into believing that the term sovereignty actually has only one meaning. In fact, these different meanings cannot easily be reduced to one another, and I believe theoretical reflections on sovereignty could be significantly enriched by paying more attention to these semantic distinctions.

\section{Political sovereignty}

Although the word sovereignty covers a wide variety of meanings, one element always returns and is hardly contested, namely the idea of 'supreme power' ('summa potestas'). Sovereignty has something to do with holding the highest or the most dominant position within a certain population. ${ }^{5}$

The most straightforward way to understand this notion of supreme power is in factual terms. Sovereignty can then be defined as the empirical capacity to impose one's will or enforce one's decisions within the bounds of a given community, territory or institutional structure. Like in an army, the sovereign is the supreme commander in the polity. I call this understanding of sovereignty 'political sovereignty'.

4 For a similar attempt to classify the different meanings of the term sovereignty, see Antonia Waltermann, Sovereignties (PhD-thesis) (Maastricht: Maastricht University, 2016). A very different attempt to order - what he calls - 'the internal variety' of the concept of sovereignty, is provided by Neil Walker. See Walker, 'The Variety of Sovereignty,' in Sovereignty Games, ed. Rebecca Adler-Nissen and Thomas Gammeltoft-Hansen (New York: Palgrave Macmillan), 21-32.

5 But note that, historically, sovereignty did not necessarily indicate the 'highest' position; it simply indicated that one was in a position to govern. One could be sovereign all while being subordinate to a higher power, and there could be several sovereigns operating on the same territory. Cf. Dieter Grimm, Sovereignty, 14; Raymond Carré de Malberg, Contribution à la théorie générale de l'etat. Tome I (Paris: Dalloz, 2004), 74. 
Jean Bodin, Thomas Hobbes, John Austin, and Carl Schmitt, among others, are often read as advocates of such a command view of sovereignty. ${ }^{6}$ Jean Bodin, in his Six livres de la république, defined sovereignty as 'the absolute and perpetual power of a commonwealth' and, in reference to the Hebrew term for sovereignty, he associated sovereignty with 'the highest power of command'. ${ }^{7}$ Similarly, Thomas Hobbes's Leviathan is sovereign because he holds real, empirical power. For Hobbes, the status of the sovereign cannot be detached from his physical capacity to enforce law, prevent civil war, keep invaders out, and maintain the security of the citizens. ${ }^{8}$ The command view of sovereignty finds its most blunt expression in John Austin's positivism. Austin unambiguously defines the sovereign as an individual or an entity habitually obtaining obedience within a society, yet itself not normally obeying the commands of any other individual or entity. ${ }^{9}$

In the command theory of sovereignty, the sovereign's empirical capacity to obtain obedience ('political sovereignty') is usually wedded to the sovereign's status as the source of valid law (cf. infra: 'legislative sovereignty'). ${ }^{10}$ Carl Schmitt's position in this regard is peculiar and is worth discussing in somewhat greater detail. Schmitt famously defines the sovereign as 'he who decides on the exception'. ${ }^{11}$ For Schmitt, an entity (that is: an association of human beings) is sovereign if in critical situations, when there is an acute danger to the existence of the polity, it makes the ultimate decisions - no matter how exceptional such situations are. ${ }^{12}$ This definition is intended to sever the usual connection between sovereignty and the day-to-day operations of a political and juridical system. For Schmitt, the sovereign cannot be identified by discovering who holds the dominant position within the institutionalized legal and political order, as the sover-

6 Although this is not necessarily the most accurate reading of their work (cf. infra).

7 Jean Bodin, On Sovereignty (Cambridge: Cambridge University Press, 1992), 1.

8 Thomas Hobbes, Leviathan (Cambridge: Cambridge University Press, 1996), 121 ff. Cf. Gérard Mairet, Le principe de souveraineté (Paris: Gallimard, 1997), $45 \mathrm{ff}$.

9 John Austin, The Province of Jurisprudence Determined (Cambridge: Cambridge University Press, 1995), 181.

10 Neil MacCormick, Questioning Sovereignty (Oxford: Oxford University Press, 1999), 127-8.

11 Carl Schmitt, Political Theology. Four Chapters on the Concept of Sovereignty (Chicago and London: University of Chicago Press, 2005), 5.

12 Carl Schmitt, The Concept of the Political (Chicago and London: University of Chicago Press, 2007), 38 . 
eign only appears when the normal order is suspended..$^{13}$ Thus, sovereignty is here explicitly understood as the outside of legality. Not just in the sense that the sovereign decision cannot be codified or regulated by law, but also in the sense that it shows the legal order to be dependent on a decision that has little to do with juridical abstractions and everything with the 'power of real life'. ${ }^{14}$ This is also why Schmitt - following Hobbes - has no patience for abstractions such as the 'sovereignty of law', which he derides as an empty and misleading phrase; the good observer knows that the 'sovereignty of law' really signifies 'the rule and sovereignty of men' who can appeal to this law to rule other men. ${ }^{15}$

Despite Schmitt's emphasis on rule by men over other men, it is of course more common to ascribe sovereignty to an impersonal entity, in particular to the state. The idea of the modern state implies precisely that it is an abstract institution, elevated above the citizens and even above the government, an institution that functions as the ultimate arbitrator in all domestic conflicts and that holds, at least in principle, the monopoly of violence. According to French constitutional scholar Raymond Carré de Malberg, this is the quintessential meaning of sovereignty: the term 'sovereign' points to a specific quality of the modern state, namely 'the supreme character of its power'. ${ }^{16}$ For Carré de Malberg, this indicates simultaneously the state's external as well as its internal sovereignty. And he defines internal sovereignty as follows:

Internal sovereignty implies indeed that the State posesses, in its relations to individuals who are its members or who find themselves on its territory, as well in its relations with all other private and public associations formed within it, a supreme authority; this means that its will predominates over all

13 The recently attempted coup d'état in Turkey (15 July 2016) provides a clear example of what Schmitt had in mind. While the coup plotters were already declaring on Turkey's state television that they now controlled the country's institutions, one appearance of Recep Tayyip Erdogan was enough to prove the contrary. In his famous speech on CNN Turk, channelled through a smartphone app, Erdogan commanded the population to go into the streets and physically resist the coup, a command that was obeyed by large sections of the population. At the same time, Erdogan gave instructions to police forces and to the country's muezzins, who equally obeyed. The combined efforts of police officers and ordinary citizens, encouraged by incessant calls from the muezzins, ultimately quelled the coup. Although the Turkish president justified his commands with references to the will of the people - among other things, he declared that 'there is no power higher than the power of the people' and 'Let them do what they will [with the coup plotters]' (Cf. Tim Arango and Ceylan Yeginsu, 'Turkey is Battlefield in a Coup Attempt,' The New York Times, July 16, 2016, A1) - Schmitt would argue that Erdogan proved himself the true sovereign: amidst a volatile crisis, it was his decisions that were ultimately obeyed.

14 Schmitt, Political Theology, 15. Because Schmitt connects the theme of sovereignty not only to the suspension but also to the institution of a legal order, he can equally be read as an advocate of sovereignty as constituent power. See below and see Andreas Kalyvas, 'Popular Sovereignty, Democracy and Constituent Power,' Constellations 12(2) (2005): 226, 228.

16 Carré de Malberg, Contribution à la théorie générale de l'etat. Tome I, 70. 
the wills of these individuals and associations, whose powers are inferior to the state's. ${ }^{17}$

Although Carré de Malberg emphatically believes it is properly an attribute of the state, he admits that sovereignty can also be ascribed to the concrete person holding the office which, within the state, carries the highest power. And indeed, historically this usage came first. Before being a property of the state, the term sovereign was used to describe the personal role of the monarch. Martin Loughlin explains well how the office of the monarch was slowly 'idealized' and how his various powers were gradually differentiated (into 'the king-in-council', 'the king's courts', et cetera). Eventually, this made it possible to ascribe sovereignty to the state apparatus rather than to the monarch himself. ${ }^{18}$ Hobbes is sometimes credited as the first to consciously distinguish between the state, as an artificial person, and the individual person who, like an actor, carries the mask of the state and gives voice to it. But as Quentin Skinner notes, there are several authors before Hobbes (such as Bodin himself or, less well known, the royalist Dudley Digges) who occasionally used the word 'state' to indicate that abstract 'institution we create by the act of submitting to government'. ${ }^{19}$ Yet as Skinner also emphasizes, Hobbes is certainly the first to appreciate the conceptual challenges that emerge when using the word 'state' in this way. One can for instance wonder how an abstract person can act, or why the citizens should submit to its purported actions. ${ }^{20}$

The distinction between the abstract institution of the state and the concrete person holding the highest power accompanies the rise of the modern state in the sixteenth and seventeenth century and was an historic breakthrough. But it long caused unease, for instance among contractarians (such as Locke) and republicans, who feared that attributing sovereignty to the state implies taking it away from citizens. It was also resisted in France, where absolute monarchs liked to think of sovereignty as an innate right which does not originate in the state but which they received by divine law, thereby turning sovereignty again into an individual attribute. ${ }^{21}$ The distinction was also lost on Austin, and thereby on a lot of English positivist theorists. ${ }^{22}$

18 See Martin Loughlin's contribution to this special issue ('The Erosion of Sovereignty') and see Martin Loughlin, Foundations of Public Law (Oxford: Oxford University Press, 2010).

19 Quentin Skinner, Visions of Politics. Volume 2: Renaissance Virtues (New York: Cambridge University Press, 2002), 400-2.

20 Hobbes's answer to the first question is that the state can be represented by a sovereign (the concrete person of the monarch) whose actions are attributed to the state. His answer to the second question is that the sovereign state's actions are the citizens' own actions, as they have authorized the state to act in their name. Ibid., 403-4.

21 To illustrate this evolution, Carré de Malberg (Contribution à la théorie générale de l'etat. Tome I, 78) cites Louis XV's well-known statement: 'Nous ne tenons notre couronne que de Dieu'.

22 Cf. Skinner, Visions of Politics. Volume 2: Renaissance Virtues, 406-7. 
Summarizing all this, we can see that the term sovereignty, understood as political sovereignty, can be used to qualify at least two different entities: the abstract person of the state, and the concrete person(s) holding supreme power within this state. A third option can be added to this, namely the institutional 'organ' or 'office' of which these concrete persons are the temporary occupiers. It can for instance be said that sovereignty belongs to the office of the monarch (rather than to the person of the king or queen), to the institution of parliament (and not necessarily to its current members), or to the Roman consulate (rather than to the actual consuls). But no matter what type of entity one ascribes sovereignty to, in all these cases this ascription means that this entity wields supreme political power within a given territory or community.

The notion of political sovereignty can be split up further in de jure and de facto. Whereas de facto political sovereignty would imply the effective capacity to predominate over the wills of all individuals and associations, a de jure political sovereign would be an entity officially entitled to use force and obtain general obedience, without necessarily being able to do so. ${ }^{23}$ This distinction can be relevant in times of unrest, civil war, or foreign occupation. Think of a country where the old state apparatus continues to be de jure politically sovereign, but is no longer capable of effectively playing that role, for instance because a hostile militia wields much more force and is now the only entity capable of obtaining general obedience within this territory. This military force (or the top of its chain of command) can then plausibly be described as de facto politically sovereign. A good example is the way Bashar al-Assad remains in many people's eyes de jure sovereign in the whole of today's Syria, even if in large parts of the country he clearly is not de facto sovereign anymore. Of course, such a separation between de facto and de jure political sovereignty is unlikely to be stable and workable for very long.

\section{Legislative sovereignty}

Political sovereignty is primarily internal in that it concerns the domestic institutions of an organized community. But the term sovereignty can also be used to point out another element that is internal to a community's institutional structure, namely what can be called the 'legislative sovereign' or the 'juridical sovereign'. Sovereignty, in this sense, indicates the highest source of valid law within a community, and possibly a source of valid law that is not itself subject to any higher norms. Legislative sovereignty differs - at least analytically - from political sovereignty, and one can easily imagine cases where they are also practically distinct. Think for instance of a sophisticated theocracy where a small club of wise theologians is considered the sole fountain of valid law (and thus functions as the legislative sovereign), while political sovereignty rests with another authoritative institution within the state (or is ascribed to the state itself). 
Of course, we are today accustomed to seeing political and legislative sovereignty as closely related, or even as indistinguishable. In the modern state as Rechtsstaat, political and legislative sovereignty are intricately interwoven. ${ }^{24}$ The rule of law in such a state not only implies that public powers should be exercised in the name of the state and in accordance with its laws, it also implies that the state - as an abstract point elevated above citizens and officials - is the sole source of valid law. If in earlier times there could be sources of law, such as the church, that did not fall under the dominion of the political ruler, the modern state claims to be the exclusive origin of valid law on its territory. Only the laws made in accordance with the procedures stipulated in its basic statutes should be enforced, and the state should in principle have sufficient power to enforce all laws without tolerating any competing powers on its territory. Hobbes was, again, among the first to describe this apparently indissoluble link between political and legislative sovereignty. According to Hobbes, our civil condition depends on the presence of a state, capable of holding the monopoly of violence. In this civil condition, we accept the person(s) holding sovereign power as the unique source of valid law. If there would be competing sources of law or if we would refer to something as contestable as 'right reason' to legitimate laws, natural strife would return.

Despite this historical entanglement of political and legislative sovereignty, certain developments suggest that we are currently witnessing their disentanglement. In today's European Union, EU law has primacy over domestic law implying that the European lawgiver is now the legislative sovereign. Yet the member states jealously guard their political sovereignty and the EU has no means of its own to effectively enforce its laws. A Schmittian would probably argue that sooner or later this ambiguity will be resolved and that in a moment of crisis the true sovereign will be revealed. ${ }^{25}$ But for the time being, the separation is maintained. ${ }^{26}$

Just like political sovereignty, legislative sovereignty can be ascribed to various types of entities. In Austin's view, the legislative sovereign (who is by definition also the political sovereign) is simply one person or possibly a group of persons. The presence of this person (or this group) is a sufficient condition for the existence of a legal system, as laws are nothing but the commands of this sovereign. However, as pointed out by later legal positivists and by Hans Kelsen and H.L.A.

24 Martin Loughlin writes that the political and legal aspects of sovereignty can 'be compared to the double helix of DNA, in which the political and legal run as anti-parallel strands' (see Loughlin, 'The Erosion of Sovereignty', in this special issue).

25 Cf. Stefan Rummens and Stefan Sottiaux, 'Democratic Legitimacy in the Bund or 'Federation of States': the Cases of Belgium and the EU,' European Law Journal 20(4) (2014): 568-87. As mentioned by Martin Loughlin in his contribution to this special issue, one could even argue that the emergency measures taken during the Eurocrisis prove - in this Schmittian manner - that the national governments have already lost their sovereignty.

26 Some authors argue that something similar is happening on a global scale. Cf. Neil Walker, Intimations of Global Law (Cambridge: Cambridge University Press, 2015). 
Hart in particular, such a view is not particularly plausible. ${ }^{27}$ The sheer possession of superior power is not enough to turn one's commands into law, nor to give addressees an obligation to comply. Typically one can only make valid laws after being formally appointed to do so. Also, making laws requires following certain procedures, procedures that bind even the purported sovereign. Moreover, laws tend to outlive the person (or persons) who issued them, raising the issue of continuity.

These well-rehearsed problems strongly count against ascribing legislative sovereignty to a concrete person (or group of persons). Certain contemporary authors even claim that these problems should make us abandon all talk of sovereignty in the domain of law. Pavlos Eleftheriadis, for instance, has made exactly this point. According to Eleftheriadis, lawmaking is a function within the normative framework of an ongoing legal system, and it is absurd to assume that the lawmaker would somehow have a supreme power that is not bound by this normative framework and that elevates him above it. ${ }^{28}$ Hence, the very concept of sovereignty is incompatible with the rule of law and is simply out of place when thinking about the process of lawmaking.

A strategy that avoids these difficulties consists in ascribing legislative sovereignty to the state. An example of this strategy is Carre de Malberg's so-called 'organ-theory' of state sovereignty. Although the state, as an abstract entity, cannot directly act as lawgiver itself, various persons and institutions ('organs') can issue law in its name. And while such persons and institutions are bound to certain rules, it is the state itself that is seen as the ultimate depository and guarantor of these rules. Moreover, the state has a permanent existence across time, allowing law to attach itself to an unfaltering source of validity. Carré de Malberg's scheme, or some version of it, is today deeply embedded in our constitutional imagination. It is hardly possible to think of a reference point other than the state that can provide the stability which law needs so badly, which is why we still find it difficult to picture law without the state.

Yet if the state can only act as a lawgiver by making use of 'organs', would it not be more plausible to ascribe legislative sovereignty, not to the state in its entirety, but rather to the specific organ responsible for lawmaking? If this organ (or "office" or "institution") is excusively competent to create new laws, then it seems only logical to describe it as the legislative sovereign. This is the idea behind the English doctrine of parliamentary sovereignty, which gained dominance after the prudence, $\operatorname{XXIV(2)~(2011):~473-90.~}$

28 Pavlos Eleftheriadis, 'Law and Sovereignty,' Law and Philosophy 29(5) (2010): 535-69. Eleftheriadis repeats the gist of this argumentation in his article in this special issue ('Power and Principle in Constitutional Law'). This line of argumentation has a long and venerable history, going back to - at least - eighteenth century constitutionalism, see for instance Keith Michael Baker, Inventing the French Revolution. Essays on French Political Culture in the Eighteenth Century (Cambridge: Cambridge University Press, 1990), 41-4. 
Glorious Revolution. ${ }^{29}$ Based on various sources ranging from medieval traditions to the political writings of Locke, parliamentary sovereignty implies that Parliament is the unique and supreme legislative power and can make any law it wants. There are no limits - especially no legal limits - to its authority, and no person or institution can override its legislation. ${ }^{30}$ Parliament is of course understood here, not as the set of its current members, but rather as the formal institution that is convened and that produces law by following specific procedures, with a key role for majority voting.

Thus, just like political sovereignty, legislative sovereignty can be ascribed either to specific persons, or to the state as an abstract entitity, or to an organ, an office, or a specific institution within the state. But in all these cases, what we mean when we call such an entity sovereign is that it is the highest source of valid law within a given polity.

Can legislative sovereignty, like political sovereignty, be subdivided into de jure and de facto? I believe this is possible, although this opens a familiar can of worms. ${ }^{31}$ From a strictly descriptive or positivist perspective, such a distinction is certainly problematic. For starters, it can be observed that de facto juridical authorities invariably claim that they are also de jure juridical authorities. ${ }^{32}$ And if the task of legal theory is indeed to observe or describe the way empirically existent legal systems work, then we might have to agree that whatever entity is de facto accepted as legislative sovereign within a certain community is also the de jure legislative sovereign. This is also the lesson suggested by Hart. If we want to know what counts as valid law within a specific legal community, Hart recommends us to look for the rule of recognition that is operative within this community. Reaching beyond the rule of recognition is simply impossible, as this rule is not itself covered by any further laws or norms. ${ }^{33}$

29 Note that it is now often argued that the primacy of EU law has invalidated English parliamentary sovereignty, especially since the Factortame case in the early 1990s (cf. Nicholas Barber, 'The Afterlife of Parliamentary Sovereignty,' International Journal of Constitutional Law 9(1) (2011): 144-54). Obviously, Brexit might imply a reversal of fortunes for the doctrine of parliamentary sovereignty.

30 I am following here the classical account of A.V. Dicey as discussed by Jeffrey Goldsworthy. See Goldsworthy, The Sovereignty of Parliament. History and Philosophy (Oxford: Clarendon Press, 1999); Goldsworthy, Parliamentary Sovereignty. Contemporary Debates (Cambridge: Cambridge University Press, 2010), 274-5 and elsewhere.

31 Note that the distinction between de facto and de jure is somewhat ambiguous here. One can actually ask three relevant questions of a legislative sovereign. Does this sovereign entity, in the actual facts, function as the highest source of law? Is this entity, in the actual facts, accepted by the population as the rightful source of law? Is this entity-from a normative perspectiverightfully entitled to function as the highest source of law? As every question can be answered with yes or no, this results in eight types of legislative sovereignty. (One could do the same exercise for political sovereignty.) In the text, when discussing the possible distinction between de facto and de jure legislative sovereignty, I am merely inquiring whether a sovereign for whom the first two questions are answered positively, can nonetheless receive a 'no' on the third question.

32 As Joseph Raz, among others, reminds us. Cf. Raz, 'Authority and Justification,' Philosophy \& Public Affairs 14(1) (1985): 3-29, at 6.

33 H.L.A. Hart, The Concept of Law (Oxford: Oxford University Press, 1994). 
According to Jürgen Habermas, this implies that even Hart collapses the dimension of validity into the dimension of facticity. ${ }^{34}$ By emphasizing the rule of recognition as the ultimate source of legitimacy, Hart inevitably reduces the question of legal validity to the sociological question of what is de facto accepted as valid law within a given community. ${ }^{35}$ Habermas also shows us a possible way out of this conundrum. According to Habermas's discourse theory, laws can only be valid if they are the consensual result of a rational procedure, that is, a procedure that is inclusive and in which only the force of the better argument counts. In consequence, there can be a de facto legislative sovereign (an entity that is functioning and that is accepted within a given territory as the highest source of valid law) which is not de jure sovereign (because the lawmaking procedures are insufficiently rational).

Theological natural law promises a different solution to this same problem. By postulating a transcendent source of valid law, it becomes conceivable that a de facto legislative sovereign (for instance a parliament creating laws) is not de jure sovereign; its very claim to legislative supremacy would already be a form of blasphemy.

\section{Original constitutive power}

When talking about political or legislative sovereignty, we talk about persons or entities occupying key roles within an institutionalized order. Yet in democratic thought it is generally assumed that such an order has its origins outside or before itself. The basic rules and norms that establish a community's institutional life might, legally speaking, have no further source or justification (concepts such as Hart's 'rule of recognition' and Kelsen's 'Grundnorm' point exactly to these outer limits of legal logic). But it might still be possible to describe the legal system in its entirety as the volitional product of an entity that is somehow prior to the constituted legal order and hence prior to all legal norms. The traditional French name for this entity is 'pouvoir constituant', usually rendered in English as constituent or constitutive power. In order to distinguish it from 'constituted constitutive power' (cf. infra), I will here use the formula 'original constitutive power' to refer to this extra-legal source of a legal system.

Invoking original constitutive power usually serves to justify a democratic institutional order, and this justification typically operates by describing this institutional order as somehow 'willed' or 'created' by the subjects themselves. ${ }^{36}$ Depending on philosophical sympathies, the subjects qua pouvoir constituant can racy (Cambridge, Mass.: MIT Press, 1996), 202.

35 One can of course also read Hart in a more charitable way, especially when taking into account the new 'Postscript' to The Concept of Law.

36 While the notion of sovereignty can potentially be used in the context of various political regimes, its usage to refer to original constitutive power is deeply interwoven with democratic politics. 
be given different names, such as 'the people', 'the nation', or 'the multitude'. Yet in all these cases the basic idea is the same: original constitutive power is invoked to make it clear that the institutional rules, as well as the powers held by various officials and institutions, are not natural or God-given, but have their ultimate origin in the human beings that are subjected to these powers and institutions. ${ }^{37}$

Richard Tuck, in a recent book entitled The Sleeping Sovereign, argues that the usage of the term sovereignty to refer to constitutive power is the conceptual innovation of modern political thought, in particular because it opened the path towards democracy as we now know it. ${ }^{38}$ For a very long time, conventional wisdom had it that democracy was impossible in large European countries, a belief that had its root in the association of democracy with direct popular participation in quasi-permanent, Athens-style councils. This fixation on the Greek example was eventually broken with the help of an all-important distinction that, according to Tuck, was first introduced by Bodin and Hobbes and received its most lucid expression in the writings of Jean-Jacques Rousseau. ${ }^{39}$ This is the distinction between 'sovereignty' ('summum imperium' or 'summa potestas') and 'government' ('administratio').

As mentioned above, Bodin is often interpreted as an early advocate - or even the inventor - of the command view of sovereigny. Yet Tuck shows that Bodin also introduces a rather more subtle idea. When analysing the institutional structures of government one can discover who holds the highest political or legislative power within these structures. But for Bodin this is not the end of the story: 'Hidden underneath those structures and possibly apparent only at very long intervals was [according to Bodin] a different kind of power which gave legitimacy to these other institutions' ${ }^{40}$ It is for this other power that Bodin ultimately reserves the term 'sovereignty'. This sovereign is not necessarily involved in the actual government, but is responsible for choosing the type of government, laying down the basic laws, and appointing the magistrates. In consequence, it becomes possible that what appears to be a monarchy (because in day-to-day politics the highest power is exercised by a monarch) is in fact a democracy (because the citizens themselves instituted the monarchical form and appointed the king). Or, inversely, what appears to be a democracy (because the citizens themselves exercise power by sitting on various councils) might really be a monarchy (because it is a monarch who gave them these rights).

Tuck also undermines the Austinian reading of Hobbes. In his early works, Hobbes adopts Bodin's distinction between sovereignty and government, yet

37 For a comprehensive overview of the different meanings that have historically been given to the term 'constituent power', see Joel Colón-Ríos, 'Five Conceptions of Constituent Power,' Law Quarterly Review 130 (2014): 303-36.

38 Richard Tuck, The Sleeping Sovereign. The Invention of Modern Democracy (Cambridge: Cambridge University Press, 2016).

39 Note that Tuck's history of constitutive power upends many received views of how this notion emerged (e.g. Andreas Kalyvas, 'Popular Sovereignty, Democracy and Constituent Power').

40 Tuck, The Sleeping Sovereign, 27. 
adds a democratic twist to it. In De Cive he argues that men who join together to form a commonwealth, convene voluntarily and necessarily subject themselves to the will of the majority and are hence by default a democracy. Whether they decide to form an actual democratic government or, say, a monarchy, it matters little as in all these cases it is their will that reigns, be it through a popular assembly or in the person of the king. ${ }^{41}$

According to Tuck, Rousseau consciously follows in Hobbes's footsteps and equally believes that the general will originally resides in 'a democratic assembly governed by majority voting. ${ }^{42}$ Yet Rousseau modifies Hobbes's scheme on one important point. For Hobbes, the people in council can appoint a monarch without setting a date to meet in council again, in which case the people should be understood to have dissolved themselves. Sovereignty has then irreversibly been transferred to the monarch. Rousseau, in contrast, refused to believe that the 'sovereign legislature could transfer [...] its sovereignty to another person or assembly'. ${ }^{43}$ Rousseau had no problem accepting that the government acted as the sovereign's agent in the business of daily politics and even in making important decisions, for instance about war and peace. But the government could never represent the sovereign as sovereign. This means that Rousseau took the difference between sovereignty and government more seriously than anyone before him, leading to his famous conclusion that sovereignty lies in the general will, is inalienable, and cannot be represented. Of course, the sovereign does not have to be permanently active - something which Rousseau rejected as wildly implausible in a large, commercial society - most of the time it can be asleep. But at regular intervals it has to wake up and fulfil its task of making fundamental, 'general' laws. By redefining democracy in this way (the people do not have to be the actual government, it is enough that they are the sovereign) the road to democracy in the modern world was opened.

Despite the important contributions of Bodin, Hobbes, and Rousseau, it is the philosopher, revolutionary and politician Emmanuel Joseph Sieyès who became most famous for distinguishing the business of ordinary politics and lawmaking from the more fundamental task of establishing the constitution and erecting the various powers of government. ${ }^{44}$ The former he called the domain of the constituted powers or 'pouvoirs constitués', the latter is the domain of the constitutive power or 'pouvoir constituant'. This vocabulary, first introduced in his 1789 pamphlet on the Third Estate, served to defend the people - or the 'Nation', as Sieyès

41 Ibid., $86 \mathrm{ff}$.

42 Ibid., 129

43 Ibid., 139. In this regard Rousseau comes closer to Locke, who similarly held that the people never completely lost their 'supreme power'.

44 Richard Tuck, in The Sleeping Sovereign, seems eager to discount Sieyès's contribution, in particular because Sieyès did not defend the idea that the people should exercise constitutive power through constitutional referendums (instead arguing that even constitutive power should be exercised through representative procedures) (ibid., $162 \mathrm{ff}$.). But this is somewhat arbitrary. Why would a theory of constitutive power only count as such when it includes the claim that constitutive power should be exercised through referendums? 
preferred to put it - as the fundamental, extra-legal and unrestricted source of constitutional law:

Not only is a nation not subject to a constitution, it cannot and should not be [...]. However a nation may will, it is enough for it to will. Every form is good, and its will is always the supreme law. [...] There is no reason to be afraid of repeating the fact that a nation is independent of all forms and, however it may will, it is enough for its will to be made known for all positive law to fall silent in its presence, because it is the source and supreme master of all positive law. ${ }^{45}$

In this famous passage, Sieyès emphatically argues that the Nation, in contrast to the various constituted powers, is by definition prior to the constitution and can hence never be subjected to it. While Sieyès introduced the term 'pouvoir constituant' with a clear and straightforward purpose (defending the rights of the commoners against the crumbling Ancien Régime), the term eventually gave rise to a wide variety of interpretations and theoretical speculations, especially with regard to the precise relation between this original power and the established order. One can for instance claim that original constitutive power is 'extra-legal' and 'prior' to the constituted powers in a merely chronological sense. In this case, original constitutive power refers to the power exercised by the persons who were present and participated when, in a revolutionary moment, the new polity was created. ${ }^{46}$ Yet the term is more often used in a non-chronological sense so as to refer to a power that is permanently lurking underneath the constituted system. This sovereign power does not have to be constantly active - it can be 'sleeping' yet it might wake up at any time to reassert its primacy over the constituted powers of government.

45 Emmanuel Joseph Sieyès, Political Writings (Indianapolis and Cambridge: Hackett, 2003), 137-8.

46 Antonio Negri sometimes uses the term in this sense, for example in his description of the events of the American Revolution. Negri strongly emphasizes the material character of this revolution: the establishment of armed militias in the colonies (the 'people-in-arms') was a real moment of innovation and a crucial act of 'constituent power' (Negri, Insurgencies. Constituent Power and the Modern State (Minneapolis and London: The University of Minnesota Press, 1999), $146 \mathrm{ff}$. .). In general, though, Negri has something different and more fundamental (and more idiosyncratic) in mind when referring to constituent power. For Negri, true constituent power seems to be a radical, contestatory, destructive power that can always erupt; instead of aiming to take control of the state and institute law, it 'seeks rather to destroy State power altogether and refuse any relation to law' (Michael Hardt and Antonio Negri, Labor of Dionysus: A critique of the State-Form (Minneapolis: University of Minnesota Press, 2003), 294-5). See also Nora Timmermans, 'Terug naar het begin: Een onderzoek naar het principe van constituerende macht,' Netherlands Journal of Legal Philosophy 44(2) (2015). 
A related ambiguity concerns, again, the de facto versus the de jure usage of the term. In certain cases, the term is used in a clearly de facto manner. ${ }^{47}$ Think for instance of an historical analysis where the notion of original constitutive power indicates the raw forces that generated the institutional order. The same would go for a sociological analysis that describes the constitutive forces upholding, on a daily basis, the constituted order. Constitutive power would then refer to the psychological fact of support by citizens, who, by their daily participation in the legal and political order (or at least by their acquiescence) allow this order to endure. ${ }^{48}$ Yet the idea of original constitutive power can also be invoked in a de jure manner, without making any descriptive claim. In this case, the term refers to an entity that should be considered the source of all legal and political powers and therefore holds normative priority over these constituted powers. Think for instance of a situation where the constitution is promulgated 'in the name of the people', while it is openly admitted that the people played no role whatsoever in establishing the new order.

An extreme example of de jure usage is provided by the 1831 Belgian constitution as it is traditionally interpreted. A key article of this constitution (Art. 33) states that 'all powers emanate from the Nation', which suggests that the 'Nation' is the original constitutive power. At least since 1950, the official reading claims that the term Nation in this context indicates the complete set of all Belgians, including past, present and future generations. ${ }^{49}$ Defined in this way, the Nation is clearly a de jure sovereign that can never appear in the actual facts.

Note that, in actual political practice, invoking original constitutive power is usually done for symbolic reasons. For opponents of pouvoir constituant, this is also the notion's greatest weakness. The absence of a materially existent constitutive power that genuinely precedes the constituted order, ${ }^{50}$ as well as the legal impossibility of giving its will normative priority over all established rules, should be

When used in a strictly de facto manner, the notion of original constitutive power comes close to Schmitt's understanding of sovereignty, as the 'founding power' (die begründende Gewält) which in times of crisis appears and imposes its will in a decisive manner (cf. Kalyvas, 'Popular Sovereignty, Democracy and Constituent Power,' 226). The case of Erdogan is exemplary in this regard as well. By successfully imposing his will on the ongoing events Erdogan is not just recapturing state power, he is also restructuring Turkey's political and legal institutions to the point of constituting a new institutional order (with, for instance, restricted civil liberties, a stronger emphasis on Turkey's islamist identity, and an altered role for the army).

48 Think of Renan's famous definition of the nation as a 'daily plebiscite'.

49 This reading, unquestioningly transmitted by courts and constitutional scholars alike, has become dominant in Belgium in the postwar period, but is probably erroneous. See Raf Geenens and Stefan Sottiaux, 'Sovereignty and Direct Democracy: Lessons from Constant and the Belgian Constitution,' in European Constitutional Law Review 11(2) (2015): 293-320; Brecht Deseure, 'National Sovereignty in the Belgian Constitution of 1831. On the Meaning(s) of Article 25,' in Reconsidering Constitutional Formation I. National Sovereignty, ed. Ulrike Müßig (Sl: Springer, 2016), 93-157.

50 In an enlightening essay, Martin Loughlin has criticized this tendency to think of constitutive power as brute factuality, a tendency he describes as a 'materialist fallacy'. See Martin Loughlin, 'The Concept of Constituent Power,' European Journal of Political Theory, 13(2) (2014): 218-37. 
sufficient to dispel this notion for good. ${ }^{51}$ But this would be to overlook that even a merely symbolic invocation of original constitutive power might have important practical effects. For instance, the claim that the constituted powers of government derive from the people, even if factually inaccurate, does transform the relation between the government and its subjects, and might render resistance against the forces of government more acceptable. Think also of the Belgian case, where making the Nation (understood as a transgenerational entity) the original constitutive power has had the momentous effect of making national referendums unconstitutional. ${ }^{52}$

\section{Constituted constitutive power}

Pouvoir constituant is typically defined as the extra-legal or extra-constitutional source of a constitutional order. While regular laws are produced by the regular lawmaking organ (the 'legislative sovereign'), higher law (or constitutional law) is purportedly the product of this pouvoir constituant. Higher lawmaking might involve changes to the division of powers, redistributing competences across various policy levels, defining basic liberties, modifying the electoral system, and so on. Of course, most contemporary constitutional systems have specific procedures in place for making such changes, procedures that are usually more rigorous than the ordinary lawmaking procedures. ${ }^{53}$ This leads to a paradoxical situation. When applying such procedures, we should say that constitutive power is at work because basic norms are being produced or redefined. ${ }^{54}$ But this is strange as this exercise of constitutive power is established and framed by constitutional norms - it is 'constituted' - whereas constitutive power was defined as the very opposite of constituted power.

This situation should not surprise us. It was always difficult to imagine how original constitutive power would be exercised in absence of institutionalized proce-

51 See for example Eleftheriadis, 'Parliamentary Sovereignty and the Constitution,' 290; Eleftheriadis, Law and Sovereignty, 553 ff., 567.

52 Referendums, it is argued by Belgium's Council of State, would be an usurpation of the nation's will by a limited number of today's citizens. The nation's will can supposedly only be determined by the careful deliberation of elected representatives. See Raf Geenens and Stefan Sottiaux, 'Sovereignty and Direct Democracy: Lessons from Constant and the Belgian Constitution'.

53 The United Kingdom is a remarkable exception in this regard.

54 In Belgian jurisprudence, the term is used very explicitly (and apparently without any awareness of the paradox). The procedure for amending the constitution requires declaring a number of constitutional provisions open for revision, followed by the dissolution of the House of Representatives and the Senate. After new elections, the newly elected Parliament can effectively revise the constitution. It now acts - so it is typically said - as 'constituent power'. See Patricia Popelier and Koen Lemmens, The Constitution of Belgium. A Contextual Analysis (Oxford and Portland: Hart, 2015), 39 ff. 
dures. ${ }^{55}$ Moreover, it is only natural that constitutional democracies want to entrench their basic norms and statutes more solidly than regular laws (and certainly do not want to make them dependent on random expressions of constitutive will). But for theories of constitutive power this remains an important puzzle. On the one hand, we like to define constitutive power as an extra-institutional, sometimes almost ontological power that founds the polity. But in practice, constitutive power turns out to be just another function of government, exercised through specific procedures that are stipulated in the constitution.

In French legal theory, the preferred solution for this theoretical puzzle consists in making a sharp distinction between on the one hand 'original constitutive power' ('pouvoir constituant originaire') and 'constituted constitutive power' ('pouvoir constituant constitué). ${ }^{56}$ While the former refers to the purported extra-institutional source of political and juridical institutions, the latter refers to the competence of higher lawmaking as exercised through institutionalized procedures. Thus, when used in the sense of constituted constitutive power, sovereignty refers to the entity which, within the established order, is officially appointed to make fundamental changes to the legal and political system, typically by following rigid procedures.

While all democracies need some proceduralized way to alter their constitution, opinions as to what these procedures should be differ wildly. Rousseau himself, in his Considerations on the Government of Poland, proposed a system of mandated delegates. ${ }^{57}$ Sieyès, during the French Revolution, argued in favour of a dedicated circuit of political representatives, distinct from regular representatives and not bound to an imperative mandate so as to allow for genuine deliberation. ${ }^{58}$ In sharp contrast to this, the Girondin faction (including the marquis of Condorcet) came to advocate plebiscitary referendums: the introduction of a new constitution, but presumably all further constitutional revisions as well, had to be approved in a majoritarian vote by the complete electorate. Such 'constitutional referendums' were actually pioneered in Massachusetts in 1778, and are today widespread and often seen as the optimal way to organize constituted constitutive power. ${ }^{59}$ On the other hand, it is clear that referendums have severe short-

55 This is the so-called 'paradox of constitutionalism': in order to constitute institutions and procedures, one cannot but make use of institutions and procedures. For further discussion, see Martin Loughlin and Neil Walker, ed., The Paradox of Constitutionalism: Constituent Power and Constitutional Form (Oxford: Oxford University Press, 2007).

56 Yaniv Roznai claims that this distinction, which he also calls the distinction between 'constituent power' and 'amendment power', was born in the debates in the French National Assembly prior to 1791. Cf. Roznai, 'Towards a Theory of Unamendability,' New York University Public Law and Legal Theory Working Papers (2015): 15-22.

57 Tuck, The Sleeping Sovereign, $143 \mathrm{ff}$.

58 Ibid., $163 \mathrm{ff}$. Note that in 1789 , Sieyès was still of the opinion that the new, upcoming constitution would have to be ratified in a general referendum. But he would soon abandon this position. See Ibid., 164 and see Lucien Jaume, 'Constituent Power in France: The Revolution and its Consequences,' in The Paradox of Constitutionalism. Constituent Power and Constitutional Form, ed. Martin Loughlin and Neil Walker (Oxford: Oxford University Press, 2007), 70. 
comings as decision procedures, and it is increasingly admitted that referendums are ideally combined with deliberative processes so as to improve the quality of decision-making and stimulate the citizens' involvement. ${ }^{60}$ In certain places, highly complex set-ups are being tested, involving citizen panels drawn by lot, mixed panels with elected politicians, interaction through social media, feedback from traditional political institutions, and possibly a referendum to close the process. ${ }^{61}$ While the level of sophistication is new, the basic concern remains the same (and remains as paradoxical) as in the eighteenth century: how to let the people, qua constitutive power, appear and act within a system of constituted powers.

The term constituted constitutive power is relatively rare, but the notion of Kompetenz-Kompetenz, popular in recent debates about the European Union, can be considered a prime example of it. The Kompetenz-Kompetenz is the special competence to transfer political or legislative competences from one level of government to another, and it is often seen as a token of sovereignty. ${ }^{62}$ It is for instance claimed that EU member states, although subjected to EU-law, nonetheless remain sovereign because their governments keep the Kompetenz-Kompetenz firmly in their own hands. The Kompetenz-Kompetenz is clearly a form of constituted constitutive power (it is a formally recognized competence of governments), distinct from both political and legislative sovereignty, as well as from the original constitutive power that might be its deep, extra-legal foundation.

\section{External sovereignty}

The four meanings of sovereignty listed above are all 'internal' in that they refer to the domestic life of a legal or political community. In theory, the term sovereignty could meaningfully be used in any of these four senses even in a polity 'without an outside', e.g. a polity that does not interact with other polities or a unified world state. In reality, however, the term sovereignty rose to prominence in a Europe of Westphalian states and is therefore closely connected with the status of a polity as an autonomous actor that is present and active on the stage of independent states. This then points to a fifth meaning of the term, namely sov-

60 See Stephen Tierney, Constitutional Referendums. The Theory and Practice of Republican Deliberation (Oxford: Oxford University Press, 2012); and see Peter Leyland, 'Referendums, Popular Sovereignty, and the Territorial Constitution,' in Sovereignty and the Law, ed. Richard Rawlings, Peter Leyland and Alison L.Young (Oxford: Oxford University Press, 2013), 154-64.

61 See for instance Hélène Landemore, 'Inclusive Constitution-Making: The Icelandic Experiment,' Journal of Political Philosophy 23(2) (2015): 166-91.

62 See for instance Cezary Mik, 'State Sovereignty and European Integration: Public International Law, EU Law and Constitutional Law in the Polish Context,' in Sovereignty in Transition, ed. Neil Walker (Oxford: Hart, 2003), 369. Note that even a judicious scholar of sovereignty, Michel Troper, uses the term sovereignty in this sense (when arguing that the French state, despite its membership of the EU, currently remains sovereign because the rules concerning the distribution of competences remain under its control), without clearly distinguishing it from other usages of the term. See Michel Troper, 'Sovereignty,' in The Oxford Handbook of Comparative Constitutional Law, ed. Michel Rosenfeld and András Sajó (Oxford: Oxford University Press, 2012), 359. 
ereignty as 'external sovereignty'. A polity is sovereign in this sense when it is not dependent on another state, when it does not usually suffer interference from other states in its domestic affairs, and when it is recognized as such by the international community of states.

Once again, there might be circumstances where the notion of external sovereignty is used in a strictly de facto manner (to refer to the effective condition of a country that is not interfered with by others), or in a strictly de jure manner (to refer to the official status of a country as a sovereign entity in international law and international institutions). Political history is filled with examples of countries that were de jure sovereign but not de facto, or the other way around.

Does external sovereignty require the presence of internal sovereignty? In principle it does not. One can imagine a territory and a population (for instance a stretch of desert, sparsely populated by nomadic families) that is respected as independent by the international community, even if it lacks the internal political and juridical structures of sovereignty. This shows that the meaning of external sovereignty is logically independent from other uses of the term sovereignty. ${ }^{63}$ Yet in practice internal and external sovereignty are closely related. ${ }^{64}$ Historically, external sovereignty has always required the capacity to conclude binding treaties with other states, and it is unclear how this could be done without an internal, centralised hierarchy. ${ }^{65}$ This also suggests that external sovereignty, rather than being a mere expression of political and legal autarky, normally points to a form of mutual recognition in the community of interacting states. In the initial Westphalian system, state sovereignty could maybe still be understood in a more autocratic manner, as 'existing apart from and prior to' the international interactions between states. ${ }^{66}$ But in the world that emerged after World War II, the relational aspect has become absolutely central to our understanding of external sover-

63 Cf. MacCormick, Questioning Sovereignty, 129.

64 Robert Jackson, in his introductory book on sovereignty, strongly emphasizes the interdependence of external and internal sovereignty. See Robert Jackson, Sovereignty (Cambridge: Polity, 2007), 12 and elsewhere.

65 As is also confirmed by the Montevideo Convention, which requires sovereign states to have a government and to be capable of establishing relations with other states. For a contemporary assessment of the Montevideo Convention, as well as a clear-eyed overview of the conceptual difficulties in defining sovereign states, see Thomas D. Grant, 'Defining Statehood: The Montevideo Convention and its Discontents,' Columbia Journal of Transnational Law 37 (1999): 403-57. Of course, it does not follow that external and internal sovereignty need to be exercised by the same entity. They can be exercised by different 'organs' of the same state, or they can be seen as different 'powers' of government (as in old theories about the separation of powers, such as Locke's), but they can also be devolved to completely different levels of government.

66 Cf. Jean Cohen, Globalization and Sovereignty. Rethinking Legality, Legitimacy, and Constitutionalism (Cambridge: Cambridge University Press, 2012), 201. 
eignty. ${ }^{67}$ According to Jean Cohen, the principle of 'sovereign equality' formulated in the United Nations Charter (Art. 2) is expressly meant to emphasize this relational aspect. The United Nations embodies the international community, and states are today sovereign because they are recognized as equal holders of 'legal personality' within this community. This means that they 'have an equal entitlement to participate in the formation of international law (as legal subjects) and to take on international obligations' ${ }^{68}$ Just as domestic citizenship is inconceivable without the existence of a domestic legal and political order, so is sovereignty - citizenship in the global community - today inconceivable without the existence of well-ordered global institutions.

For Cohen, this also implies that the traditional connection between sovereignty and 'absoluteness', i.e. a government's entitlement to do whatever it wants both at home and abroad is definitively cut. Membership in the global community today depends on accepting certain limitations that are non-negotiable. For starters, the transition to the principle of sovereign equality already forced states to shed many of their external privileges: 'States gave up their 'sovereign' right to go to war, aggression and annexation became illegal, colonialism was dismantled, and 'empire' became a pejorative term'. ${ }^{69}$ But the limitations also extend inwards. It is now a permanent fixture of our world that if a government gravely violates the human rights of its subjects, it opens itself to interferences from the global community, interferences that can range from mere naming and shaming to fullblown military invasions and long-term occupation. According to the so-called 'political conception' of human rights, this is the key role of human rights today: human rights are the triggering criteria for the suspension of external sovereignty. ${ }^{70}$ In the words of Joseph Raz, human rights are these 'rights which set limits to the sovereignty of states [...]. They disable, or deny the legitimacy of the response: I, the state, may have acted wrongly, but you, the outsider are not entitled to interfere. I am protected by my sovereignty'. ${ }^{71}$ This political conception of human rights, as advocated by Raz, Rawls, Cohen, and many others, is meant to describe today's sovereignty regime: ${ }^{72}$ a world that is composed of sovereign states, but where the sharpest edges of sovereignty (e.g. governments hiding

67 Michel Troper argues that this relational element has always been a part of sovereignty: 'Being sovereign never meant to be unbounded by treaties. On the contrary, being bound by treaties to which he had consented meant that the sovereign was only bound by his own will. The capacity to make treaties and be bound by them was thus viewed not as a limitation but as an expression of sovereignty-Bodin placed it among the attributes of sovereignty, as part of the power of making war and peace' (Troper, 'Sovereignty,' 359).

68 Cohen, Globalization and Sovereignty, 200.

69 Ibid., 202.

70 Jeremy Waldron offers a very persuasive criticism of the political conception of human rights, see Waldron, 'Human Rights: A Critique of the Raz/Rawls Approach,' New York University Public Law and Legal Theory Working Papers. Paper 405 (2013).

71 Joseph Raz, 'Human Rights Without Foundations,' in The Philosophy of International Law, ed. Samantha Besson and John Tasioulas (Oxford: Oxford University Press, 2010), 328, 332.

72 Cf. Raz, 'Human Rights Without Foundations'; John Rawls, The Law of Peoples (Cambridge, Mass.: Harvard University Press, 1999); Cohen, Globalization and Sovereignty. 
behind their sovereign status to abuse their own subjects) are filed off by binding international norms. ${ }^{73}$

Appealing as this picture of the world may be, many authors claim that it is deeply anachronistic. They argue that we have decidedly moved beyond such a statist world, and have now entered a 'post-sovereign condition'. In the discipline of legal theory, Neil MacCormick was probably the first to emphatically push this point. In his 1993 text, 'Beyond the Sovereign State', he famously argued against those who worried about the United Kingdom's sovereignty within the EU:

A different view would be that sovereignty and sovereign states, and the inexorable linkage of law with sovereignty and the state, have been but the passing phenomena of a few centuries, that their passing is by no means regrettable, and that current developments in Europe exhibit the possibility of going beyond all that. On this view, our passing beyond the sovereignty state is to be considered a good thing, an entirely welcome development in the history of legal and political ideas. ${ }^{74}$

The literature on post-sovereignty is too large to summarize here ${ }^{75}$ but it goes without saying that the end of sovereignty in the external sense of the word will also have profound effects on all other meanings of the term. Indeed, this is exactly Neil MacCormick's claim. According to MacCormick, the EU not only shows us a path beyond a system of states endowed with external sovereignty, it also puts into question the need to concentrate all political and legal authority in one single point, an article of faith in most classical theories of sovereignty. Moreover, MacCormick - as opposed to many other observers - is strongly convinced that our exiting the realm of sovereignty is not a threat, but rather a golden opportunity to democratize processes of government at all levels. ${ }^{76}$

\section{Conclusion}

The bulk of this essay has been dedicated to differentiating between the various meanings of the term sovereignty, leaving me with little room to answer the question announced in the title. Is it possible, out of these manifold meanings, to distil one 'master meaning' from which all the other ones naturally flow? Strictly speaking, I think the answer should be no. It is true that the element of 'supreme

For criticism of Jean Cohen's views on sovereignty, see Raf Geenens, 'The Emergence of Supranational Politics: A New Breath of Life for the Nation-State?' Telos 156 (2011): 24-46.

74 Neil MacCormick, 'Beyond the Sovereign State,' The Modern Law Review 56(1) (1993): 1.

75 A good starting point is the collection Sovereignty in Transition (ed. Neil Walker), which, as one reviewer put it, reads like a 'juridico-political bestiarium' that covers a wide range of theoretical alternatives to the traditional, statist sovereignty regime (cf. Jens Bartelson, 'The Concept of Sovereignty Revisited,' The European Journal of International Law 17(2) (2006): 474). See also David Held, 'Law of States, Law of Peoples: Three Models of Sovereignty,' Legal Theory 8 (2002): 1-44.

MacCormick, Questioning Sovereignty, 133-6. 
power' is somehow present in all meanings of the term sovereignty. But even with that element of commonality, the term sovereignty still refers to such a variety of things that it is almost outlandish to always use the same term. The term appears in the doctrine of parliamentary sovereignty, in theories of pouvoir constituant, and in studies of international relations, yet the concepts at play are so different that the relation between these different usages of the word sovereignty comes close to being merely homonymic.

This is insufficiently recognized in the contemporary debate on sovereignty. All too often an impression is created that, because the same word is used, one is also discussing the same issue - even when this is patently not the case. For instance, those who argue against sovereignty because the concept is supposedly incoherent would do well to indicate what usage of the term is exactly under threat, as their criticisms might leave other usages untouched. Maybe not, but even clarifying this would require more conceptual attention to the term's manifold meanings. Similarly, those who claim that sovereignty no longer exists today usually start by describing the disappearance of 'external sovereignty' but then draw farreaching conclusions about sovereignty in general, without taking into account that certain other forms of sovereignty might perfectly well persist.

This latter point is of particular importance. I am convinced that even in 'postnational' or 'post-sovereign' conditions, many aspects of sovereignty can and should be conserved. As I argue elsewhere, the myriad uses of the term sovereignty, despite their disparities, do all serve one unique and normatively valuable cause: no matter how the term is used, it always helps to create and sustain the perspective from where a political community can consciously understand itself as an autonomous agent. ${ }^{77}$ In this regard, I would claim that there is a unity underneath the different meanings of the word sovereignty, but it is a unity of purpose rather than of meaning. That purpose is establishing an image of society as an autonomous entity. The term sovereignty always refers to some way or other in which society can be consciously steered, instead of being a loose collection of individuals whose interactions are controlled by merely empirical mechanisms. Whether it is a central office of command, a source of binding norms, a theory on political society as the volitional product of its subjects, the institutionalized capacity to alter society's basic norms, or the status of being recognized as independent by other societies; in all these cases the notion of sovereignty helps society to see itself in a specific way, namely as a unit of intentional collective action.

This is also why the idea of sovereignty is such a good match with the idea of democracy, and why the transition to a post-sovereign condition is usually perceived as a threat to democratic self-government, that is, to the possibility of popular sovereignty. If we do indeed evolve towards a world without sovereign states, citizens might no longer feel part of a collective agent able to steer its course on the basis of shared reasons, and might instead have the feeling that they are sub- 
jected to blind societal or economic laws. This makes it highly urgent to understand what elements of the sovereign state can be rescued in our post-sovereign world, and how. Certain meanings of sovereignty seem more important in this regard than others. Democracy as popular sovereignty at least implies that original constitutive power as well as constituted constitutive power are attributed to the people. Legislative and political sovereignty should probably be exercised in the name of the people as well, even if representation will always be involved and even though the need to centralize all legislative and political powers can be questioned. The link between popular sovereignty and external sovereignty seems contingent to me, although I have to admit that the internal and external meaning of sovereignty have been interwoven for so long that our imagination struggles to untie them.

But this is not the place to conduct this debate in full. My principal claim here is that this debate requires its participants to be more careful towards the different meanings of the term sovereignty than they usually are. And I strongly hope that the distinctions proposed in this article will help some way in that direction. 